\title{
Bir Gıda Güvenliği ve Să̆lık Sorunu: Balık ve Balık Ürünleri Kaynaklı Alerjenler
}

\author{
İsmail Hakkı TEKİNER \\ Istanbul Sabahattin Zaim Üniversitesi, Să̆lık Bilimleri Fakültesi, \\ Beslenme ve Diyetetik Bölümü, Ístanbul. \\ ismail.tekiner@izu.edu.tr; https://orcid.org/0000-0002-7248-2446
}

Murat AY

İstanbul Doğuş Üniversitesi, Sanat ve Tasarım Fakültesi, Gastronomi ve Mutfak Sanatları Bölümü, İstanbul. may@dogus.edu.tr; https://orcid.org/0000-0002-3872-3920

\section{Hayrettin MUTLU}

İstanbul Gedik Üniversitesi, Sağlık Bilimleri Fakültesi, Beslenme ve Diyetetik Bölümü, İstanbul. hayrettin.mutlu@gedik.edu.tr; https://orcid.org/0000-0002-6560-5831

\section{Öz}

Gıda alerjisi, önemli bir gıda güvenliği ve halk sağlığı sorunudur. Gıda alerjenleri cilt ve sindirim sistemi rahatsızlıklarından başlayarak, anaflaktik şok gibi yaşamı ciddi şekilde riske atan alerjik reaksiyonlara kadar yol açmaktadır. İnsan beslenmesinde önemli yeri olan balık ve balık ürünleri, alerjik vakalardan sorumlu ß-parvalbumin maddeler gibi sağlık riskleri de taşımaktadır. Balık ve balık ürünleri, dünyada gıda kaynaklı alerjilerin neredeyse $\% 95$ 'inden sorumlu ilk sekiz besin maddesi arasındadır. Gıda Kodeksleri, balık ve balık ürünlerini alerjen bileşenler veya alerjen işlem yardımcıları olarak kabul etmekte ve ürün etiketinde belirtilmesini zorunlu tutmaktadır. Avrupa Alerji ve Klinik İmmünoloji Akademisi, balık ve balık ürünlerinde $\beta$-Parvalbumin üst miktarını $0,1 \mathrm{mg} / 100 \mathrm{gr}$ balık eti olarak vermektedir. Bu çalışmada, bir gıda güvenliği ve sağlık sorunu olan balık ve balık ürünleri kaynaklı alerjenler hakkında okuyucuya bilgi vermek amaçlanmıştır.

Anahtar Kelimeler: Alerjen, balık, balı ürünü, gıda alerjisi, gıda güvenliği 


\title{
A Food Safety and Health Issue: Fish and Fish Products Allergens
}

\begin{abstract}
Food allergy is a severe issue of food safety and public health. The allergens of food-origin mainly cause some symptoms such as dermatitis and gastrointestinal disorders, even leading to potentially life-threatening reaction called anaphylaxis. Fish and fish products are not only a valuable source of nutrients, but also a potential source of $\beta$-parvalbumins responsible for allergic reactions, leading to severe life-threatening health risks. Fish and fish products are among the first eight foods responsible for $95 \%$ of the foodborne allergic cases all over the world. All the food codexes has listed the fish and fish products as the common causes of allergic reactions, and included on the list of foods and ingredients that must be declared on food labels. The European Academy of Allergy and Clinical Immunology has determined the upper level of ß-parvalbumine in fish and fish products as $0.1 \mathrm{mg} / 100 \mathrm{~g}$ fish meat. The objective of this study was to inform the reader about fish and fish products allergens that are considered as a food safety and health issue.
\end{abstract}

Keywords: Allergen, fish, fish product, food allergy, food safety

\section{GİRIŞ}

G1daalerjisi; birgıdayadag1dakatkımaddesinin oral yolla vücuda alımından sonra, immün sistem tarafindan yabancı olarak algilanıp, bu duruma karşı beklenmedik immünolojik tepki oluşması durumudur. Bu immünolojik tepki toksik ya da toksik olmayan şeklinde ikiye ayrılmaktadır. Toksik olmayan gida alerjileri immünolojik mekanizmalara göre $\mathrm{IgE}$ aracilı ve IgE aracilı olmayan olarak siniflandirılır. Toksik yanitlarda alerjik maddenin dozu önemli iken, toksik olmayan yanıtlar için kişisel duyarlılık söz konusudur (Kocatepe ve Turan, 2012; Karakılıç, Suna, Tamer, Çopur, 2014). Gida alerjisi, gida intoleransindan farklıdır. Gıda intoleransı bağışıklık sistemiyle ilgili olmayan bir tepki olup, g1da alerjisi ile karıştırılmakta ve çok daha sık görülmektedir (Şimşek, Yılmaz, Yüksel, 2014). Gıda alerjisinin kesin bir tedavisi bulunmamaktadir. Gıda maddeleri arasında alerjik ölümcül olgulardan en sık fistık, kabuklu kuruyemişler, kabuklu deniz ürünleri ve balık sorumlu tutulmaktadır (Özdemir, 2014).
Bu çalıșmada, bir gıda güvenliği ve sağlık sorunu olan balık ve balık ürünleri kaynaklı alerjenler hakkında okuyucuya bilgi vermek amaçlanmıştır.

\section{Gıda Alerjisi: Dünya ve Türkiye’de Durumu}

Alerji tanımı, ilk kez 1906 y1lında Clemens von Pirquet tarafından yapılmıştır. Ancak, gidaların insanda olumsuz tepkilere yol açtığ1 2000 yıldan uzun süredir bilinmektedir. Hipokrat'ın kayıtlarında inek sütüne karşı gelişen reaksiyonlardan bahsedilmektedir. Tanımlı alerjenlerin 200'ü gıda kaynaklı olup, yaklaşık 90 farklı türden izole edilmiştir. Gıda alerjenlerinin \%70’i bitkisel, \%30’u ise hayvansal kaynaklı gıdalarda tanımlanmıștır (Dibek-Misırlıoğlu ve Bostanc1, 2013). Gıda alerjenlerine duyarlı kişiler için cilt ve sindirim sistemi rahatsızlıklarından başlayarak, anaflaktik şok gibi yaşamı ciddi şekilde riske atan alerjik reaksiyonlara kadar yol açmaktadır. Bu sebeple çoğu ülke alerjik tüketiciler için gıda yönetmeliklerinde önemli 
alerjenleri belirtmiş ve ürün etiketlerinde uyarı bulunmasını şart koşmuştur. Ancak, alınan bu tedbirler, alerjik kişilerin tüketecekleri gıdalarda istenmeyen çapraz bulaşmaları engellememektedir. Özellikle endüstrileşmiş ülkelerde gıda kaynaklı alerjik kişi prevalansı yetişkinlerde \%2, genç ve çocuklarda \%4-8 arasinda tahmin edilmektedir (Bogh ve Madsen, 2016). Bir diyet proteinini gida alerjeni yapan mekanizmalar nelerdir sorusunun kesin biryanıtı henüz verilememiştir. Araştırmacılar, oral yolla alınan bir gıda alerjeninin gastrointestinal traktüste mukozal immün sistemi duyarlılaştırmasının arkasında proteolitik mekanizmaya karşı direnç göstermesi ile sağladığını düşünmektedirler. Bir diyet proteinin potansiyel olarak alerjik olup olmadığına tek bir karakteristiğine bakarak karar vermek yeterli görünmemektedir. Bir risk değerlendirmesi sürecinde yapıldığ 1 gibi adımsal ve durumsal yaklaşım uygulanmalıdır. $\mathrm{Bu}$ aşamalarda, alerjeni kodlayan genetik materyalin kaynağı, karakterize edilmiş diğer alerjenler ile benzerlik ve farklılıkları, gen ekspresyonu seviyeleri, serum plazmada IgE düzeyi, pepsin degradasyonuna dirençlilik durumu, hücre kültürü analizi ve hayvansal deneyler gibi çok sayıda aşamayı geçmesi gerekmektedir (Sofronova vd., 2016).

Alerjen adlandırması, alerjik maddenin izole edildiği türün adının ilk 3-4 harfi ve cins adının 1-2 harfi alınarak ve sonuna rakam eklenerek yapılır. Örneğin, ilk alerjen ev tozunda yaşayan bir tür akar (mite) olan Dermatophagoides pteronyssinus'ten elde edilmiştir. Bu alerjik madde "Der p 1 adı verilmiştir (Radauer vd., 2014). Tespit edilmiş alerjen bileşikler, moleküler, biyokimyasal ve klinik verileri uluslararası veri tabanları tarafindan tutulmakta ve güncellenmektedir. $\mathrm{Bu}$ veri tabanlarından başlıcaları arasında;
Allergome (www.allergome.org), Allergen (www.allergen.org), Research Collaboratory for Structural Bioinformatics Protein Data Bank (RCSB PDB) (www.rcsb.org) ve Allallergy (allallergy.net) gibi veri tabanları gelmektedir. Günümüzde tanımlanmış 700 farklı alerjen bulunmaktadır. Yeni keşfedilen alerjenler, bu alerjenlerin homologları ve isoformları adlandırması ve kayıt altına alınması Dünya Sağlık Örgütü (WHO) ve Uluslararas1 İmmünoloji Dernekleri Birliği (IUIS) organizasyonuna bağlı bir alt komite (InformAll Allergenic Food Database, WHO/ IUIS Allergen Nomenclature Sub-committeewww.allergen.org) tarafından yürütülmektedir.

Dünyada gıda kaynaklı alerjilerin neredeyse \%90'indan sekiz gida maddesi (yumurta, süt, fistıklar, ağaç findıkları, kabuklu deniz hayvanları, soya, buğday ve balık) sorumludur (Valenta, Hochwallner, Linhart, Pahr, 2015). Son yillarda gida kaynaklı alerjik vakaların görülme sıklığında yükseliş olduğu görülmüştür (Tang ve Mullins, 2017). Örneğin, A.B.D Hastalık Kontrol ve Korunma Merkezleri (CDC) 2013 yılı raporuna göre 1997 ve 2011 yılları arasında gida kaynaklı alerjik semptomların görülme sıklığının \%50 arttığı bildirilmiştir (Jiménez-Saiz, Benedé, Molina, López-Expósito, 2015).

Dünya Alerji Örgütü (WAO) tüm Dünya'da 200 ila 250 milyon insanın gida kaynaklı alerjik durumlar yaşadığını, her y1l ortalama 250.000 kişinin alerjik olumsuzluklar sebebiyle hayatını kaybettiğini ve sağlık hizmetlerinde ciddi mali yükler getirdiğini bildirmiştir. WAO'ya göre 2007 yılı itibariyle gıda kaynaklı alerjik olguların Avustralya'da 9,4 milyar A\$, A.B.D'de 19,7 milyar \$ ve Finlandiya' da 519,7 milyon $€$ ek mali yük getirdiği raporlanmıştır. WAO tarafindan 2012 yılında gerçekleştirilen 
küresel gıda alerjisi paternleri ve prevalansı başlıklı araştırmaya toplam 98 ülke dâhil edilmiştir. Ancak, bu ülkelerden \%53,1 $(n=52)$ 'i veri sunamamıştır. Güvenilir bilgiler, ancak gida alerjileri takip sistemine sahip 9 $(\% 9,2)$ ülke tarafından verilebilmiştir. Yirmi üç ülke ise yalnızca ailelerin gıda kaynaklı alerjik durumlar hakkında beyanlarını esas alarak hareket etmiştir. Gıda kaynaklı alerjik vakalar hakkında veriler özellikle 10-15 yaş arası çocuklarda dikkat çekici şekilde yetersiz kalmaktadır. Özellikle endüstrileşmiş ülkelerde gıdalara karşı immünolojik veya non-immünolojik alerjik tepkilerin görülme sıklı̆ğ genç çocuklarda \%10'a ve yetişkinlerde \%2-3'e yükselmiştir (Pawankar, 2014; Walker, Burns, Elliott, Gowland, Mills, 2016; Fernandes, Costa, Carrapatoso, Oliveira, Mafra, 2017).

Türkiye Sağlık Araştırması verilerine göre, 15 yaş ve üstü bireylerde en çok görülen hastalık türleri incelendiğinde, alerjik vakaların prevalansı \%10,8 ile dikkat çekmektedir (Türkiye İstatistik Kurumu [TÜíK], 2016). European Food Safety Authority (EFSA) gıda alerjisi prevalansını belirlemek amaçlı hazırladığı raporda Türkiye çıkışlı sadece altı adet klinik kökenli yayına atıf yapılmıştır. Bu klinik bulgulara göre, Türkiye'de, yumurta, süt ve süt ürünleri (Altıntaş vd., 1995), yumurta, kanatlı eti, süt ve süt ürünleri, kabuklu yemişler, muz, çikolata, patlıcan, sarımsak, üzüm, mantar, şeftali, salatalık, deniz ürünleri, baharatlar, çilek ve domates (Gelincik vd., 2008), yumurta, süt ve süt ürünleri (Küçükosmanoğlu vd., 2008a; Küçükosmanoğlu vd., 2008b), yumurta, balık, süt ve süt ürünleri, kabuklu yemişler, muz, sığır eti, nohut, karabiber ve kakao (Orhan vd., 2009) ile yumurta, balık, süt ve süt ürünleri, fistık ve kabuklu yemişlere (Mustafayev vd.,
2013) bağlı alerjik vakalar incelenmiştir. EFSA raporu dişında, kendisi aynı zamanda WAO üyesi olan "Türkiye Ulusal Alerji ve Klinik İmmünoloji Derneği”" tarafından çıkarılan “Astım, Alerji ve İmmünoloji” dergisi arşivinde hastanelerin immünoloji kliniklerine başvuran hastalarda, buğday unu (Y1lmaz ve Mungan, 2017), baklagiller (Yılmaz vd., 2016), yumurta (Ünsel, Ardeniz, Mete Gökmen, 2013), polen ve tohum (Cebeci vd., 2011) ile çaşır otuna (Ünsel, Çakır, Kaya, Ardeniz, 2011) immünolojik reaksiyon geliştiği görülmüştür. Türkiye'de balık kaynaklı alerjik bulgu sunan yalnızca bir araştırma tespit edilmiştir. Kılıç ve Taşkın (2015), geleneksel Türk mutfağının Orta Doğu ve Akdeniz mutfaklarına benzerlik gösterdiğini, bu sebeple, süt ve süt ürünleri ile yumurtanın alerjik gıdaların başında geldiklerini, et, tahillar, baharatlar ile baklagillerin bu besinleri takip ettiklerini rapor etmiştir.

\section{Dünya ve Türkiye'de Su Ürünleri Üretimi}

Dünya toplam su ürünleri üretim miktarı 2014 yılı istatistiklerine göre 167,3 milyon ton'dur. Bu üretimin 93,4 milyon tonu $(\% 55,8)$ avcılık ve 73,8 milyon tonu $(\% 44,2)$ kültür balıkçılı̆̆ 1 ile sağlanmıştır. Gıda ve Tarım Örgütü (FAO) kültür balıkçıllğını Dünya'da son on yılda en çok büyüyen gida üretim sektörü olduğu bildirmiştir. Türkiye'de kültür balıkçıllı̆g 1 1970'li yıllarda gökkuşağı alabalığ ve sazan üretimi ile başlatılmış olup, 1985'li yıllarda çipura ve levrek, 2000'li yllarda ise orkinos üretimi ile devam etmiştir. Türkiye'de 2014 yılı itibariyle kültür balıkçılığı üretimi toplam üretiminin \%44'üne ulaşmıştır (Karataş, 2016). Türkiye'de deniz kültür balıkçılığı olarak en çok üretimi yapılan balık cinsi levrek ve çipuradır. 2013 yılı itibariyle ülkemiz, dünyanın en büyük çipura-levrek üreticisi unvanına sahip olmuştur. Levrek üretim 
miktarı 2014 y1l1 itibariyle 74,653 ton ve çipura üretimi ise 2014 y1lı itibariyle 41,874 ton olarak gerçekleşmiştir. Deniz avcılığı ile yakalanan miktarlar ise 2014 y1l itibariyle levrek 110,5 ton ve çipura 606 tondur. Üretilen levrek ve çipura balıklarının $\% 75^{\prime}$ i AB ülkelerine ihraç edilmekte ve geri kalan yurt içinde tüketilmektedir. Türkiye'nin 2023 y1lı itibariyle su ürünleri üretiminin 600,000 tona çıkacağı ve ticari değerinin 5 milyar TL seviyesine ulaşacağı öngörülmektedir (Aydın, 2016; Tarım ve Orman Bakanlığı [TOB], 2017).

\section{Balık ve Balık Ürünleri Kaynaklı Alerji: Dünya ve Türkiye'de Durumu}

Balık alerjisi ilk kez 1921 yılında Prausnitz ve Kustner tarafından tanımlanıştır (DibekMisırlığlu ve Bostanc1, 2013). İlk tespit edilen alerjen parvalbuminler Baltık morinası balığından "Gad c 1" ve Atlantik salmon balığından "Sal s 1" adlı bileşiklerdir (Kocatepe ve Turan, 2012). Balıkların kasları fizyolojik görevleri ve bileşimleri birbirlerinden farklı açık ve daha koyu renkli iki dokudan oluşmaktadır. Balık kaynaklı alerjik vakaların \%95'inden sorumlu olan Parvalbumin ekspresyonunun daha açık renkli dokuda gerçekleştiği düşünülmektedir. Günümüzde resmi olarak 12 balık cinsinden tespit edilen 21 adet Parvalbumin bulunmaktadir (Kuehn, Swoboda, Arumugam, Hilger, Hentges, 2014). Parvalbuminler 10-13 kDa boyutunda küçük, suda çözünür, termal ve enzimatik bozulmaya karşı son derece dayanıklı protein yapılardır. Parvalbumin kas sarkoplazmasinda serbest intrasellüler kalsiyum geçişini kontrol ederek kas kasılmasını sağlar. Alerjik olmayan $\alpha$-parvalbuminler ve alerjik $\beta$-parvalbuminler olarak iki alt gruba ayrilırlar (Fernandes, Costa, Oliveira, Mafra, 2015). Parvalbuminler dışında, balıklarda enolozalar, aldolazlar ve balık jelatini gibi yeni alerjik yapılar tanımlanıştır. Balık alerjenleri kendilerine karşı oluşmuş antikorun, yapı bakımından kendilerine benzer diğer alerjenler ile de reaksiyona girmesi olasılığı yüksek yapılardır. $\mathrm{Bu}$ bulgular balık kaynaklı alerjinin düşünülenden daha karmaşık olduğunu göstermektedir (Allergen, 2014). Balık, ilk sekiz gida maddesi arasında IgE aracilı g1da alerjisi etmenlerinden birisi olarak, gıda üreticileri ve gıda kontrolün ile halk sağlığından sorumlu otoritelerin artan şekilde ilgisini çekmektedir (Sun, Liang, Gao, Lin, Deng, 2009). Türkiye'de G1da, Tarım ve Hayvancılık Bakanlığı 2011 yılı Türk Gıda Kodeksi Etiketleme Yönetmeliği'nde 21'inci maddede belirtilen alerjen bileşenler veya alerjen işlem yardımcıları arasında balık ve balık ürünleri de bulunmaktadır. $\mathrm{Bu}$ gida maddelerini içeren ürünlerin etiketlerinde yer alması gerekmektedir. Ancak, spesifik alerjen madde adı ve limit değerine yer verilmemektedir (Türk G1da Kodeksi Etiketleme Yönetmeliği [TGK], 2011). Avrupa Alerji ve Klinik İmmünoloji Akademisi 100 $\mathrm{g}$ balık etinde "alerjen reaksiyon başlatacak dozu” 0,1 mg olarak belirlemiştir "(European Academy of Allergy and Clinical Immunology [EAACI], 2016). Balık alerjisinin dünyada görülme sıklığ1 \%0,1-0,4 arasinda değişmektedir, AB bölgesi ortalaması $\% 0,2$ ve A.B.D'de \%0,4 olduğu tahmin edilmektedir (Tang ve Mullins, 2017; Fernandes vd., 2017). Klinik verilere dayanan EFSA raporunda göre; Avrupa'da en yüksek prevalansın $(\% 0,9)$ Almanya'da olduğunu belirtmektedir. Diğer ülkeler için durum; \%0,2 ile 15-17 yaş arası gençlerde Finlandiya'da, \%0 ile 7 yaş çocuklarda İngiltere'de, \%0 ile 60-97 yaş arası yaşlılarda Macaristan' da rapor edilmiştir. Dünya'nın diğer bölgelerine bakıldığında ise, \%2,8 ile 6-9 yaş arası çocuklarda Birleşik Arap Emirlikleri'nde, \%0 ile 0-2 yaş arası 
çocuklarda İsrail'de ve 0-5 yaş arası çocuklarda $\% 0$ ile ABD'de tespit edilmiştir. Ancak, bu görülme sıklıkları her ülkede yaş ve cinsiyete göre farklılık göstermekte ve son araştırmalar balık kaynaklı alerjik vakaların görülme sıklığının tüm dünyada yükselişe geçtiğini bildirmektedir. Türk yetkililer, balık kaynaklı alerji prevalansını 6-9 yaş arası çocuklarda \%0,1-0,5 olarak vermektedir (Orhan vd., 2009; European Food Safety Authority [EFSA], 2013). Bir diğer çalışmada ise $\operatorname{IgE}$ aracılı besin alerjisi tanısı konulan çocukların içinde balık alerjisi oranı $\% 3,1$ olarak belirlenmiştir (Kılıç ve Taşkın, 2015). Bu çalışmada doğal ve kültür levrek balıklarının besin, aminoasit ve yağ asitleri kompozisyonları karşılaştırılmıştır. Ancak, alerjen düzeyleri karşılaştırılmamışıır (Baki, Gönener, Kaya, 2015).

AB Gida ve Yem Hızlı Alarm Sistemi (RASFF) 2018 y1lı raporuna göre; gida kaynaklı alerjen ikaz sayısı toplamı 158 olup, bir önceki yıla göre \%31 artış göstermiştir. Uyarıların ağırlıklı olarak nütrisyonel, diyetetik ürünleri, gida takviyeleri ve deniz ürünlerinde gerçekleştiği bildirilmiştir (Rapid Alert System for Food and Feed [RASFF], 2018).

\section{Gıda Alerjenlerinin Tespitine Dönük Çalışmaların Durumu}

Gıda alerjileri, bölgeye, yaşa ve beslenme alışkanlıklarına göre değişmektedir. Alerji konulu 7.333 adet uluslararası bilimsel yayının yalnızca \%1,9'unun gida alerjisi üzerine yapıldığını tespit etmiştir. Aralarında Türkiye de olmak üzere, Danimarka, Estonya, Finlandiya, Fransa, Almanya, Yunanistan, Macaristan, İzlanda, İsveç, İtalya, Hollanda, Norveç, Portekiz, İspanya, İsveç ve İngiltere kaynaklı gıda alerjisi konulu yayınların klinik çıkışlı oldukları görülmüştür. $\mathrm{Bu}$ yayınların \%63,9'unun "derleme makale" ve \%36,1'inin "orijinal araştırma makalesi” olarak yayımlandıkları ve süt/süt ürünleri, yumurta, deniz ürünleri ve fistık gibi gıda maddeler üzerinde durdukları anlaşılmıştır (Rencova, Kostelnikova, Tremlova, 2013). Gida alerjenlerinin tespitinde kullanılan başlıca yöntemler arasında ELISA gelmektedir. Son yıllarda gelişmeler sayesinde immunoassay teknikler, sıvı kromatgraf-kütle spektrometresi (LC-MS), polimeraz zincir reaksiyonu (PCR; PZR), real-time PCR, mikroarray ve biyosensörler artan şekilde kullanılmaya başlanmıştır. Ancak, deniz ürünleri kaynaklı alerjenlerin tespitinde kullanılabilecek teknik sayısı diğer alerjenlerde kullanılan tekniklere göre daha düşüktür (Fernandes vd., 2015). İngiltere'de 2015 y1lında gida alerjisi ve alerjen tespiti için çalışma yapılmıștır. Katılımcıların $\% 88,9$ 'u gıda alerjen analizinin çok önemli olduğunu ifade etmiştir. Katılmcıların \%63,9’u analiz taleplerinin artış gösterdiğini belirtirken, $\% 11,1$ 'i çok fazla sayıda test talebi geldiğini bildirmiştir. Gıda alerjen testi yapılabilirliği hakkında yöneltilen sorulara katılımcıların $\% 41,7$ 'si zor ve $\% 2,8$ 'i son derece zor şeklinde yanıtlamıştır. Benzer şekilde, uzmanlar gıda alerjeni tespiti ve düzeyinin konfirmasyonunun $\% 45,7$ 'si zor ve \%25,7'si kısmen zor olarak tanımlamıştır (Walker vd., 2016). Gıda eğer işlem görmüşse, kendisi de bir protein yapı olan alerjen madde denatüre olabilmekte ve test hata verebilmektedir. Ancak, DNA tabanl 1 yöntemler protein esaslı yaklaşımların bu dezavantajını ortadan kaldırmaktadır (Prado vd., 2016).

\section{SONUÇ}

Dünyadaki gıda alerjilerinin \%90'ının sebebi olan deniz ürünleridir. $\mathrm{Bu}$ gıda grubu içinde balık ve balık ürünleri ulusal ve uluslararası sağlık ve gida otoriteleri tarafindan alerjen bileşenler veya alerjen işlem yardımcıları 
arasında kabul edilmektedir ve ürünlerin etiketlerinde uyarı olarak belirtilmesi gerekmektedir. Buna rağmen, gida kaynaklı alerjik durumdan şikâyetçi kişiler, immünoloji ve alerji kliniklerine başvurmakta ve sağlik personeli tarafından genel kabul görmüş testler ile alerjinin kaynağının tespitine dönük şekilde takip edilmektedirler. Bu durum ise gıda bilimi ile uğraşan araştırmacıları gıda kaynaklı alerji konusunu disiplinler arası iş birliği ile çalışma yapmanın oldukça dışında tutmaktadır. Sonuç olarak, gıda ve sağlik alanında faaliyet gösteren her türlü kuruluş ve işletmelerin alerjenlere duyarlı kişilerin her türlü gıda kaynaklı alerjenlere maruz kalmalarını önleyecek biçimde yeterli ve doyurucu tedbirler almaları ve personelini bilinçlendirmeleri gerekmektedir.

\section{KAYNAKÇA}

Allergen. (2014). Official site for the systematic allergen nomenclature. http://www. allergen.org.

Altıntaş, D., Güneşer, S., Evliyaoğlu, N., Yüksel, B., Atıcı, A., Serbest, M. (1995). A prospective study of cow's milk allergy in Turkish infants. Acta Paediatr, 84(11), 13201321.

Aydın, H. (2016). Türkiye'de Kültür Balıç̧ı1ığ 1 Potansiyeli ve Akuakültür Sektörünün Ekonomiye Katkısı. ICOMEP 2016-International Congress of Management Economy and Policy. 26-27th October 2016, İstanbul, Turkey.

Baki, B., Gönener, S., Kaya, D. (2015). Comparison of Food, Amino Acid and Fatty Acid Compositions of Wild and Cultivated Sea Bass (Dicentrarchus labrax L.,1758). Turkish Journal of Fisheries and Aquatic Sciences, 15, 175-179.
Bøgh, K. L., Madsen, C. B. (2016). Food Allergens: Is There a Correlation between Stability to Digestion and Allergenicity? Critical Reviews in Food Science and Nutrition, 56(9), 1545-1567.

Cebeci, H., Alıç, G., Yıldırım, Ö., Pınar, N. M., Aşcı, B., Alan, Ş. (2011). Corylus avellana Polen ve Tohum Protein Profillerinin Karşılaştırılması. Asthma Allergy Immunol, 9(1), 37-43.

CODEX STAN 1-1985. (2010). Amended in 1991, 1999, 2001, 2003, 2005, 2008 and 2010 regarding the general standard for the labelling of prepackaged foods. FAO/WHO Standards, Off Codex Stand. http://www. codexalimentarius.org/standards/list-ofstandards.

Dibek Mısırlıŏ̆lu, E., Bostancı, İ. (2013). Besin Alerjisi. Türkiye Çocuk Hastalıkları Dergisi, 4, 206-213.

European Academy of Allergy and Clinical Immunology. (2016). https://www.eaaci.org/ documents/Molecular_Allergology-web.pdf

European Food Safety Authority. (2013). Literature searches and reviews related to the prevalence of food allergy in Europe. https:// www.efsa.europa.eu/en/supporting/pub/en506.

Fernandes, T. J. R., Costa, J., Carrapatoso, I., Oliveira, M. B. P. P., Mafra, I. (2017). Advances on the molecular characterization, clinical relevance, and detection methods of Gadiform parvalbumin Allergens. Critical Reviews in Food Science and Nutrition, 57(15), 3281-3296. 
Fernandes, T. J. R., Costa, J., Oliveira, M. B. P. P., Mafra, I. (2015). An overview on fish and shellfish allergens and current methods of detection. Journal Food and Agricultural Immunology, 26(6), 848-869.

Gelincik, A., Büyüköztürk, Ş., Gül, H., Işık, E., Issever, H., Özşeker, F., Çolakoğlu, B., Dal, M., Ayvaz, O., Güngör, G., Akkor, A. (2008). Confirmed prevalence of food allergy and non-allergic food hypersensitivity in a Mediterranean population. Clinical \& Experimental Allergy, 38(8), 1333-1341.

Jiménez-Saiz, R., Benedé, S., Molina, E., López-Expósito, I. (2015). Effect of processing technologies on the allergenicity of food products, Critical Reviews in Food Science and Nutrition, 55(13), 1902-1917.

Karakılıç, M., Suna, S., Tamer, C. E., Çopur, Ö. U. (2014). Gida Alerjisi Reaksiyonları. Journal of Agricultural Faculty of Uludag University, 28(1), 73-82.

Karataş, S. (2016). Balıkçılık Sektör Raporu. Ordu Ticaret Borsas1. http://www.ordutb.org. tr/pdf/BALIK\%C3\%87ILIK.pdf.

Kılıç, M., Taşkın, E. (2015). Evaluation of the clinical features of children valuation of the clinical features of children diagnosed with IgE-mediated food Allergy. Asthma Allergy Immunology, 13, 6-14.

Kocatepe, D., Turan, H. (2012). Su Ürünleri Alerjisi. Mehmet Akif Ersoy Üniversitesi Fen Bilimleri Enstitüsü Dergisi, 3(2), 46-51.

Kuehn, A., Swoboda, I., Arumugam, K., Hilger, C., Hentges, F. (2014). Fish Allergens at a Glance: Variable Allergenicity of Parvalbumins, the Major Fish Allergens. Frontiers in Immunology, 5, 179. DOI: 10.3389/fimmu.2014.00179.
Küçükosmanoğlu, E., Yazı, D., Yeşil, O., Akkoç, T., Gezer, M., Bakırcı, N., Bahçeciler, N. N., Barlan, I. B. (2008a). Prevalence of egg sensitization in Turkish infants based on skin prick test. Allergol Immunopathol (Madr), 36(3), 141-144.

Küçükosmanoğlu, E., Yazı, D., Yeşil, O., Akkoç, T., Gezer, M., Özdemir, C., Bakırcı, N., Bahçeciler, N. N., Barlan, I. B. (2008b). Prevalence of immediate hypersensitivity reactions to cow's milk in infants based on skin prick test and questionnaire. Allergol Immunopathol (Madr), 36(5), 254-258.

Mustafayev, R., Civelek, E., Orhan, F., Yüksel, H., Boz, A. B., Şekerel, B. E. (2013). Similar prevalence, different spectrum: IgE-mediated food allergy among Turkish adolescents. Allergol Immunopathol (Madr), 41(6), 387-396.

Orhan, F., Karakaş, T., Çakır, M., Aksoy, A., Baki, A., Gedik, Y. (2009). Prevalence of immunoglobulin E-mediated food allergy in 6-9-year-old urban schoolchildren in the eastern Black Sea region of Turkey. Clinical \& Experimental Allergy, 39(7), 1027-35.

Özdemir, Ö. (2014). Various clinical presentations of food allergy in children. Asthma Allergy Immunology, 12, 70-82.

Pawankar, R. (2014). Allergic diseases and asthma: a global public health concern and a call to action. World Allergy Organization Journal, 7(1), 12. DOI: 10.1186/1939-4551-712.

Prado, M., Ortea, I., Vial, S., Rivas, J., Calo-Mata, P., Barros-Velázquez J. (2016). Advanced DNA- and Protein-based Methods for the Detection and Investigation of Food Allergens. Critical Reviews in Food Science and Nutrition, 56(15), 2511-2542. 
Radauer, C., Nandy, A., Ferreira, F., Goodman, R. E., Larsen, J. N., Lidholm, J., Pomes, A., Raulf-Heimsoth, M., Rozynek, P., Thomas, W. R., Breiteneder, H. (2014). Update of the WHO/IUIS Allergen Nomenclature Database based on analysis of allergen sequences. Allergy, 69(4), 413-419.

Rapid Alert System for Food and Feed. (2018). Annual Report. https://ec.europa.eu/ food/sites/food/files/safety/docs/rasff_annual_ report_2018.pdf

Rencova, E., Kostelnikova, D., Tremlova, B. (2013). Detection of allergenic parvalbumin of Atlantic and Pacific herrings in fish products by PCR. Food Additives \& Contaminants: Part A: Chemistry, Analysis, Control, Exposure \& Risk Assessment, 30(10), 1679-1683.

Sofronova, J. K., Ilinsky, Y. Y., Orishchenko, K. E., Chupakhin, E. G., Lunev, E. A., Mazunin, I. O. (2016). Detection of Mutations in Mitochondrial DNA by Droplet Digital PCR, Biochemistry (Mosc), 81(10), 1031-1037.

Sun, M., Liang, C., Gao, H., Lin, C., Deng, M. (2009). Detection of Parvalbumin, a Common Fish Allergen Gene in Food, by Real-Time Polymerase Chain Reaction. Journal of AOAC International, 92(1), 234-240.

Şimşek, Y., Yılmaz, Ö., Yüksel, H. (2014). Çocuklarda IgE Aracılı Besin Alerjisi: Klinik, Tanı ve Prognostik Özellikler. Asthma Allergy Immunology, 12(3), 152-156.

Tang, M. L., Mullins, R. J. (2017). Food allergy: is prevalence increasing? Internal Medicine Journal, 47(3), 256-261.

Tarım ve Orman Bakanlığı. (2017). Su Ürünleri İstatistikleri. https://www.tarim.gov. tr/sgb/Belgeler/SagMenuVeriler/BSGM.pdf.
Türk Gıda Kodeksi Etiketleme Yönetmeliği (2011, 29 Aralık). Resmî Gazete (Sayı: 28157 (3. Mükerrer)). http://www.resmigazete.gov.tr/ eskiler/2011/12/20111229M3-7.htm.

Türkiye İstatistik Kurumu (2016). Türkiye Sağlık Araştırması. http://www.tuik.gov.tr/ PreHaberBultenleri.do?id=18854.

Ünsel, M., Ardeniz, Ö., Mete Gökmen, N. (2013). Erişkin Yaşta Başlayan Yumurta Alerjisi. Asthma Allergy Immunology, 11(2), 128-130.

Ünsel, M., Çakır, A., Kaya, Y., Ardeniz, F. Ö. (2011). Çaşır Otu Alerjisi. Asthma Allergy Immunology, 9(3), 166-168.

Valenta, R., Hochwallner, H., Linhart, B., Pahr, S. (2015). Food allergies: the basics. Gastroenterology, 148(6), 1120-1131.

Walker, M. J., Burns, D. T., Elliott, C. T., Gowland, M. H., Mills, E. N. (2016). Is food allergen analysis flawed? Health and supply chain risks and a proposed framework to address urgent analytical needs. Analyst, 141(1), 24-35.

Yılmaz, İ., Mungan, D. (2017). Astımı ve Buğday Unu Gıda Alerjisi Olan Bir Firıncı. Asthma Allergy Immunology, 15, 1-4.

Yılmaz, Ö., Atıcı, S., Ertoy Karagöl, H. İ., Topal, E., Bakırtaş, A., Demirsoy, M. S., Türktaş, İ. (2016). Baklagillere Alerjisi Olan Bir Olguda Deri Testi Sirasinda Anafilaksi. Asthma Allergy Immunology, 14(1), 37-41. 